\title{
IdeAs
}

Idées d'Amériques

$6 \mid 2015$

Migrer dans les Amériques

\section{Shaping immigrant and ethnic heritage in North America: ethnic organizations and the documentary heritage}

Archiver la mémoire de l'immigration: les groupes ethniques et la construction du patrimoine documentaire

Archivos de la memoria de le inmigración: los grupos étnicos y la construcción del patrimonio documental

\section{Dominique Daniel}

\section{OpenEdition}

\section{Journals}

Édition électronique

URL : https://journals.openedition.org/ideas/1089

DOI : 10.4000/ideas.1089

ISSN : $1950-5701$

Éditeur

Institut des Amériques

Référence électronique

Dominique Daniel, «Shaping immigrant and ethnic heritage in North America: ethnic organizations and the documentary heritage », IdeAs [En ligne], 6 | 2015, mis en ligne le 02 décembre 2015, consulté le 18 octobre 2022. URL : http://journals.openedition.org/ideas/1089 ; DOI : https://doi.org/10.4000/ ideas. 1089

Ce document a été généré automatiquement le 18 octobre 2022

\section{(c) (i) (2) $\Theta$}

Creative Commons - Attribution - Pas d'Utilisation Commerciale - Pas de Modification 4.0 International - CC BY-NC-ND 4.0

https://creativecommons.org/licenses/by-nc-nd/4.0/ 


\title{
Shaping immigrant and ethnic heritage in North America: ethnic organizations and the documentary heritage
}

\author{
Archiver la mémoire de l'immigration: les groupes ethniques et la construction \\ du patrimoine documentaire \\ Archivos de la memoria de le inmigración: los grupos étnicos y la construcción \\ del patrimonio documental
}

Dominique Daniel

\section{Introduction}

1 Immigrants may well be too busy to think of how the future might view them, as A. Hoglund noted in the foreword to a History of the Finns in Michigan (Holmio A. and Hoglund A.W., 2001: 7). Yet all immigrants in a new country progressively develop new identities influenced by real and imagined memories of home, the migration process, and life in the new world. During the process of "ethnicization"-the shift from immigrant to ethnic status-the experience of migration and of evolving identities become part of a group's heritage, a cultural legacy to be transmitted to future generations (Conzen K. et al., 1992). That cultural legacy rests on oral transmission, the accumulation of archival materials, the writing of histories and their public distribution. ${ }^{1}$ It is such a heritage that Marcus Lee Hansen urged the Swedish Augustana Historical Society to preserve in 1937 (Appel J., 1960: 1; Higham J., 1995: 30). The paper he was presenting, "The Problem of the Third Generation Immigrant," introduced his famous generational thesis of assimilation, summarized as "that which the son wishes to forget, the grandson wishes to remember." His thesis predicted that 
the third generation would become interested in the immigration past of their grandparents and would take steps to record their history.

More recent scholarship has shown that assimilation is not a linear progression from immigrant to ethnic to American and that ethnicity is variable; that it is not inherent but constructed by interactions between immigrants and the dominant society; and that ethnicity is therefore not something to be preserved or forgotten but a process of identification that emerges in response to particular historical conditions and may evolve or fade when the conditions change. In addition, April Schultz has convincingly argued that the apparent decline of an "ethnic" community "reveals not so much that immigrants have assimilated as that they have found other strategies to cope with changing historical conditions." She points out public performances like parades as evidence of other forms of ethnic resilience (Schultz A., 1991: 1267).

Schultz is one of several historians of immigration and ethnicity who are considering the implications of the constitution of ethnic heritage and of its public manifestations, whether for the identities of specific groups or for nations at large (Bodnar J., 1994). Many are directly or indirectly inspired by Benedict Anderson's concept of "imagined communities," applied to all kinds of communities of interest (Anderson B., 2006; Schultz A., 2009: 103). At the same time, archival scholars have argued that archives are not just what is saved of the past but what present generations have reconstructed of it. ${ }^{2}$ Ethnic heritage, in that sense, is as much a reflection of the present ethnic group as of its past. Collective memory, which memory studies since the late 1990s have seen as a legitimate conduit for the narratives of the past, is shaped by current cultural, economic and political factors and its manifestations change over time. ${ }^{3}$ It helps a group celebrate the past but also build the present and influence the future.

This article will explore some of the issues that immigrant and ethnic groups have dealt with when tackling the task of archiving-gathering and preserving the documents that tell the group's story-and that of history- or memory-building through archives, a process I will refer to, for the sake of convenience, as "ethnic archiving." The paper will trace the process of ethnic archiving through the case study of three specific groupsFinnish, German and Jewish communities in the United States-in the period preceding and following the ethnic "revival" of the 1960s. These groups were chosen because they illustrate the evolution of ethnic archiving among immigrant groups that arrived in the United States before the 1920s and the adoption of restrictive immigration laws. The similarities and differences these groups display are visible in the groups' negotiations of, and answers to, the following questions: Who should be responsible for archiving? What should be the purpose of archiving and of the transmission of migration heritage? What should be archived and transmitted? These questions have broad implications for the shaping of history and memory. ${ }^{4}$

\section{Who should be responsible for archiving?}

Finnish-, German-, and Jewish-American populations in the United States obviously have different histories. Germans and Jews make up the largest immigrant groups in the country, while Finns were a small group. In 1920, at the height of Finnish immigration, there were about 150,000 foreign-born Finns in the U.S. and about 1.7 million foreign-born German-Americans (Aaltio T., 1969: 65; Thernstrom S., Orlov A. \& Handlin O., 1980: 406). While there is no census data on religious affiliation it has been 
estimated that at least 1.1 million foreign born Americans spoke Yiddish or Hebrew in 1920 (Carpenter N., 1969: 114). In addition, German and Jewish immigration started during the colonial period and lasted into the $20^{\text {th }}$ century, while the bulk of Finnish immigration took place in the 1880s-1910s period. Germans and Jews came from a variety of countries and regimes in Europe, in several migration waves, while Finns were concentrated in a smaller, much more socially homogeneous area. The majority of Finns settled in rural areas in the northern reaches of the Midwest, while Jewish immigrants congregated in large cities. German immigrants, for their part, were found in both rural and urban areas across the country.

6 The three groups reacted differently to pressures and incentives for assimilation into the host society. They all faced some degree of alienation or suspicion at various moments of their history in the United States: German-Americans became enemy aliens during the two world wars; a portion of the Finnish-American population faced hostility, and even denial of "whiteness", for their radical political views; above all, the so-called "racial" status of Jews was long an object of debate in the age of scientific racism. However, all were eventually socially accepted as "white" (Roediger D., 2006: 61-63, 16-17, 116). A 2002 survey of Nordic Americans showed that Finnish-Americans were more likely to retain the home language and express a stronger sense of their ethnic origin than other groups (Susag C., 2002: 26). Over time, however, all three groups demonstrated an interest in preserving their past. Early on amateur historians gathered and published histories for their groups, often with an overtly filiopietistic purpose. With the desire to build a history came the need to document the past by preserving relevant books, archival materials and artefacts.

7 As mainstream Anglo-American cultural heritage institutions expressed relatively little interest in ethnic minority history until the 1950s, ethnic groups set up their own libraries, archives and museums. John Higham distinguishes three stages in the development of ethnic historical societies: Anglo-American localism (the largest part of the $19^{\text {th }}$ century), ethnic Americanism (from the 1890 s to the 1960s) and academic ethnic studies. The first period was dominated by local historical societies run by Anglo-Americans. Starting in the last two decades of the $19^{\text {th }}$ century, cultural leaders from the most settled ethnic groups established nationally-oriented ethnic historical societies modelled after their Anglo-American counterparts (Higham J., 1994: 33). Thus, the American Jewish Historical Society (AJHS) was created in 1892 and the German American Historical Society (GAHS) in 1901 (Appel J., 1960: 287; Appel J., 1962; Kaplan E., 2000). Less populous or more recently established groups focused on local initiatives for lack of resources. It was not until 1932 that the Finnish American Historical Archives (FAHA) was established in Hancock, Michigan, in 1932, and although it aimed to collect Finnish-American history as a whole it had a strong local focus (Holmio A., 2001: 391; Holmio A. and Hoglund A.W., 2001: 7-8).

8 A 1977-1978 nationwide survey of 828 ethnic cultural institutions (those supported by an ethnic community or ethnic organization) identified 64 Jewish institutions, 35 German and 9 Finnish ones that were set up at different times (Figure 1) (Wynar L.R. and Buttlar L., 1978). The numbers no doubt reflect migration peaks as well as domestic and international events for each of the groups concerned. Admittedly, the survey captured only a small portion of the many ethnic cultural institutions that existed through American history-the most resilient. 
Figure : Creation of German, Jewish and Finnish cultural institutions - by date

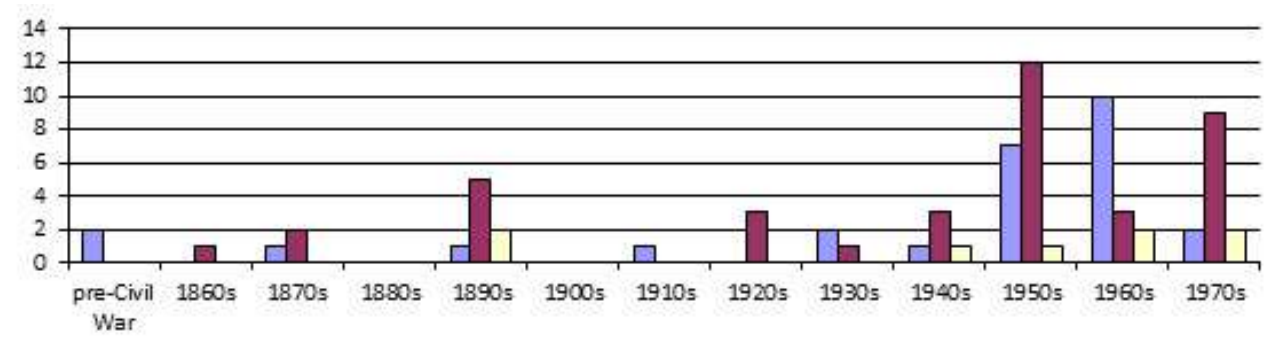

口German घlewish $\square$ Ainnish

SOURCE: WYNAR L.R. AND BUTTLAR L., 1978) 5

9 It is not surprising that those groups that succeeded in establishing strong and lasting formal institutions to preserve their past were often the largest, wealthiest and best organized groups. This does not mean that their future was guaranteed. The GAHS disbanded during World War II but was replaced by foundations after the return of peace (Appel J., 1960: 314). The Finnish American Historical Archives, which is part of a Finnish Lutheran College in Michigan, originally had no dedicated staff or space, and languished during the Great Depression and war years, before picking up speed in the 1950s: the college set aside a room, hired an archivist and developed the collections. Only when interest in ethnic studies developed, supported by mainstream institutions and government, did the institution thrive (Holmio A., 2001: 399). In 1978 it had two employees overseeing a collection of 5,000 books, 250 periodicals and 314 boxes of manuscripts (Wynar L.R. and Buttlar L., 1978: 150). The AJHS fared best because of its reliable wealthy donor base (Appel J., 1960: 219). In the 1978 survey it had 9 salaried staff members and a large collection of 60,000 books, 1,500 periodicals, and sizable archives (Wynar L.R. and Buttlar L., 1978: 197).

10 There were also multitudes of local organizations and initiatives by ethnic communities scattered across the country. The 1978 survey itself illustrates the range, with establishments that had full time staff or volunteers only, catalogued or uncatalogued collections and public services or not. Not listed in the survey are the many more that had come and gone, or that were too small and informal to be recorded. For example, in The History of the Finns in Michigan Armas Holmio notes the numerous attempts by local Finnish communities to set up historical societies and establish archival collections, only to founder over lack of popular support or funds. When they survived they fell back on less ambitious projects to celebrate their past, like public monuments or festivals (Holmio A., 2001: 386-389; Holmio A. and Hoglund A.W., 2001: 12). When it was created in 1901, the GAHS joined an already rich network of local and regional GermanAmerican historical associations (Appel J., 1960: 278).

11 Large or small, all organizations faced a number of dilemmas. On the one hand, they knew that in order to ensure the physical preservation of their recorded past some degree of professional expertise was required. In the last decades of the $19^{\text {th }}$ century museum and archival management were coming into their own as scientific fields requiring advanced education (Cook T., 2009: 501). On the other hand, professionalization would distance ethnic institutions from the community which they were intended to serve. While professional standards were out of reach of most of the 
smaller, local institutions, they were embraced by national organizations like the AJHS and GAHS.

These were largely created by Ph.D. university professors interested in serious scholarship, not popular history (Appel J., 1962; Higham J., 1994: 34). Yet throughout their history, both AJHS and GAHS had to deal with the lack of support from the Jewishand German-American populations, for lack of public outreach initiatives (Appel J., 1960: 235). The FAHA, a locally anchored archives with national ambitions, lacked staff and support but eventually hired a professional archivist. Yet its local roots and the cultural resilience of the Finnish population helped maintain its links to its constituency.

13 A related dilemma concerns control over the production of history: should the people entrusted with preserving the past be insiders, representative of the group, or could they be outsiders? Could academically trained historians, librarians and archivists of ethnic descent be representative of the group they strove to document? Could national associations represent the diverse local communities scattered across the country? Debates about these issues played into the divisions that existed within ethnic groups between foreign-born and natives, upper and lower class, urban and rural, and communities originating from different waves of migration. These debates forced participants to reconsider who belonged or not, and were often an opportunity to shift boundaries of belonging. For some, knowledge of language and culture mattered more than descent. As the Minnesota Finnish American Historical Society undertook to sponsor a book on the history of the state's Finns in 1953, its leaders decided that Finns rather than Americanized descendants of Finnish immigrants should determine "how to portray the historical record of themselves," and the Society chose a historian from Finland who wrote in Finnish (Holmio A. and Hoglund A.W., 2001: 13). Others felt that hyphenated Americans should be the focus. Thus the original leaders of the AJHS constantly struggled with defining the scope of their organization: some wanted the association to be run exclusively by descendants of early Jewish settlers of German origin and were uneasy about the negative impact they felt more recent Jewish immigrants from Russia had on the reputation of the group; some, still, felt that the AJHS should include Jews beyond the United States (Kaplan E., 2000: 139). In practice, the founders decided upon a narrowly-defined scope but under pressure were forced to progressively broaden it (Appel J.,1960: 236-244).

Professionalization accelerated toward the end of the period of ethnic Americanism, as the influence of professional historians spread through public history and the cultural heritage sector, and even more so after the 1960s with the development of ethnic history and ethnic studies in academia. In 1968 the AJSH relocated to the campus of Brandeis University (Higham J., 1994: 38). In the late 1980s professional historians, librarians and archivists from the AJSH formed a separate unit (Diner H., 2008). German-American cultural associations of the first decade of the $20^{\text {th }}$ century, promoted by community leaders, gave way to endowed groups and universitysponsored research centers such as the Society for German American Studies (Appel J., 1962: 315; Higham J.,1994: 38). In addition, mainstream archives and libraries became interested in documenting the history of immigration and ethnicity, and new institutions were set up that specialized in those areas. The Immigration History Research Center was created in 1965, followed by the Multicultural History Society of Ontario and the Balch Institute for Ethnic Studies in 1976. These relatively well-funded, 
professionally managed institutions started reaching out to ethnic organizations and individuals and amassed large multi-ethnic collections. At the same time, ethnic cultural heritage associations multiplied with the support of governmental and nonprofit grants (Figure 1).

Consequently, since the 1960s ethnic groups that were desirous to preserve their past have had a range of new options available. In some cases mainstream institutions have taken over from an ethnic counterpart. In other cases ethnic and mainstream institutions have competed with one another for ethnic materials, and some ethnic archives have chosen to maintain sole control over their heritage. Yet others have opted for partnerships with mainstream institutions. All in all, the location and rules of access to a group's heritage are issues that carry great political and symbolic significance that reflect the group's relation to society and that affects the group's collective memory, cultural retention and ethnic identity.

\section{What should be the purpose of ethnic archiving?}

16 All ethnic historical societies and related institutions share the same overarching goals: to preserve and promote the history of the group in America by collecting historical materials, publishing histories, and organizing exhibits and special events. Wynar and Buttlar hypothesize that the main motivation for the creation of cultural heritage institutions by ethnic groups is the disparity between the group and the host society: "the greater the cultural disparity, the more likely is the immigrant group to establish a greater number of cultural organizations" (Wynar L.R. and Buttlar L.,1978: xvi). Wynar and Buttlar imply that such disparity may be due to discrimination and alienation of minorities, or simply to a strong sense of distinctiveness and the desire to maintain dynamic and separate ethnic communities. While the creation of cultural heritage institutions undoubtedly reflects the group's acknowledgment of a common and distinct historical development, in practice the rationale for the preservation of ethnic heritage varied widely depending on the group's situation.

I argue that ethnic archiving at the turn of the $20^{\text {th }}$ century reflects efforts by immigrant communities to assert their members' identity as hyphenated Americans, with a dual identity, but that they did not all place the emphasis on the same side of the hyphen. Some prioritized ethnic distinctiveness while others focused more on integration and assimilation in American society. The promotion of a distinct, ethnic identity could jeopardize efforts to demonstrate Americanness, and all immigrant groups struggled with how best to balance these two objectives, especially as nativism and pressures against dual loyalties grew stronger in the United States after the 1920s. ${ }^{6}$ The choice of a historical society as carrier for historical preservation was in itself an effective way to reconcile the two. Indeed, by the second half of the $19^{\text {th }}$ century the historical society had become a popular institution in states and local communities, and several ethnic groups started creating their own. As archivist Elizabeth Kaplan observes, "The act of founding a historical society had become a demonstration of 'Americanness,' and the concept of an historical society itself was one that had the stamp of American approval" (Kaplan E., 2000: 135) Yet it made possible the preservation and promotion of the group's unique history. Still, ethnic historical societies had to be built carefully to succeed in negotiating hyphenated identities within the American framework. 

Learned, a professor of German at Johns Hopkins University. Learned saw GermanAmerican organizations as "the most important American agencies for maintaining German values and for infusing them into American civilization" (Appel J., 1960: 289) He deplored the decline of the German language and related weakening of German culture among the German-American community. At least until the United States' entry into World War I in 1917 he remained confident about the objective of revitalizing German culture in America (Appel J., 1962: 289-290). The GAHS's outlook, therefore, was first and foremost inward. At the same time, it also regarded history as an effective tool to counter accusations levied against German-Americans of radicalism and socialism, and to demonstrate German-American contributions to their adopted country (Appel J., 1962: 293). Balancing the contradictory objectives of ethnic distinctiveness and American patriotism and integration proved to be a difficult task in the context of two world wars with Germany. Russell Kazal has shown how German-Americans redefined themselves in "old stock" terms by the 1920s when faced with anti-German backslash and new south-eastern European immigrants (Kazal R., 2004). intended to strengthen and promote a cohesive Jewish identity, its main objective was to fight the wave of anti-Semitism in the United States and demonstrate the patriotism and integration of American Jews (Appel J., 1960: 205). Its mission was largely one of public outreach, unlike previous Jewish-American cultural organizations. In short, it intended to achieve the "fusion of Jewish ideals and perceived American values into a viable, public, American Jewish identity" (Kaplan E., 2000: 136). Victoria Hattam argues that Jewish intellectuals were among the first to craft the concept of ethnic identity for their community, because they strove to distance themselves from racial stigma but could not use the nationality-based hyphenated identities of other immigrant groups. Ethnicity allowed them to negotiate a compromise between assimilation and cultural pluralism (Hattam V., 2007: 46).

However some AJHS members questioned this mission as they considered that more emphasis should be placed on defining and promoting Jewishness. Eventually, that perspective would win: in 1950 the AJHS broadened its scope to include Jewish history as a whole (Appel J., 1960: 263). A related issue was the handling of national and cultural differences within the Jewish population in America. Some AJHS founders argued it would be necessary to distance themselves from recent Jewish immigration from Eastern Europe, while others considered it was essential to downplay differences and to promote commonalities among Jews (Kaplan E., 2000: 139). All things considered, both the GAHS and AJHS founders had no doubt about the effectiveness and power of the historical record as a tool to "overcome the political and social forces that confronted them" and to forge their ethnic identity in America (Kaplan E., 2000: 137).

21 After World War II and especially the 1960s, with the growing popularity of ethnic studies in academia and ethnic revival in American society, the dilemmas faced by ethnic cultural associations were in part lifted, and more emphasis could be placed on ethnic maintenance. The promotion of ethnic heritage was not just accepted but encouraged through federal and local grants (Anderson J., 1979). Politically and culturally, ethnic groups were demanding recognition and re-asserting their ethnicity. The preservation of cultural heritage consequently achieved new importance. Reactions to the American Museum of Immigration illustrate the changing attitudes of 
ethnic organizations. When the project for such a museum was conceived in 1953, planners found it difficult to get ethnic organizations involved by contributing money or artefacts for display; yet by 1972, when the museum opened its doors, ethnic leaders were prompt to criticize it for downplaying or ignoring their groups. Conceived during the Cold War, the museum appeared outdated by the early 1970s for its celebration of the melting pot and the contributions of famous immigrants to the nation's greatness. Instead, ethnic organizations demanded that each culture be recognized and celebrated separately (Blumberg B., 1985). This context may account for the multiplication of ethnic historical societies and other heritage institutions in the 1970s and 1980s (Figure 1). The roles of ethnic cultural heritage institutions diversified, as the descendants of immigrants no longer needed to prove their identities as Americans (Higham J., 1994: 39). Instead they could play an important role in the (re-) construction of ethnic identity, as well as promote intercultural dialogue and encourage cultural diversity. Thus Finnish-Americans, whose interest in cultural heritage preservation grew mostly after World War II, were largely able to avoid the concerns of the previous generations. Their preservation initiatives were inspired by a celebration of their Finnish past and Finnish nationalism. For example the Minnesota Finnish American Historical Society chose a Finnish historian to write a book in Finnish - later translated into English - and in Michigan, Holmio, a first generation immigrant, wrote his comprehensive History of the Finns in Finnish (Holmio A. and Hoglund A.W., 2001: 13-14). Many other white ethnic organizations sought to create archival and museum collections and produce histories that would present distinct ethnic identities to the American public. They still strove to build a unified image but were more open to acknowledging and documenting the diversity within groups. They intended to serve local constituencies while connecting them to transnational, diasporic cultural frameworks (Cabrera R., 2008: Higham J., 1994: 39-40). Thus hundreds of Jewish-American historical and genealogical societies spread in the 1970s with a primarily local constituency, while interest in transnational documentation of the Holocaust increased. For white ethnics, issued from older immigration waves and facing language loss and geographic dispersion, archives and museums helped create a sense of place where cultural rituals and shared meanings could foster group consciousness (Cabrera R., 2008: 158).

At the same time, archives and museums were created by and for Native American, Asian and Hispanic history (Daniel D., 2010). Among them the Chinese American Historical Society was set up on 1963 to preserve the legacy of the group, and the Japanese American National Museum was established in 1985 "to promote understanding and appreciation of America's ethnic and cultural diversity." At the political, social and academic levels, interest moved away from white ethnics and toward racial minorities. To the rhetoric of contributions was added a new discourse of resistance to oppression and challenge to discrimination. In this context, the purpose of cultural heritage preservation was redefined, and archival collections became powerful tools for political recognition. Mainstream institutions were denounced as instruments of political hegemony in which minority voices were suppressed. Some advocated reading mainstream archives against the grain, or identifying silences within it to recover marginalized voices. ${ }^{8}$ Others supported the creation of new community archives and museums by cultural minorities to avoid Eurocentrism. ${ }^{9}$ Ironically, therefore, even as they could now ascertain their ethnic distinctiveness 
without restrictions, older white ethnic cultural heritage institutions joined the mainstream - sometimes even feeling "Eurocentric" in their mission (Daniel D., 2014).

\section{What should be archived?}

ough ethnic communities who set up archives all recognized the power of the historical record, they often disagreed on the importance of collecting, publishing or even interpreting it through the writing of historical narratives. Because it was led by scholars, the main strategy of the GAHS was the reproduction and publication of historical documents and scholarly articles in the Annals, the main organ of the society (Appel J., 1962: 291). Learned, the secretary of the society, knew that the writing of serious history was predicated on the availability of archival sources. The founders of the AJHS, for their part, long debated whether building archival collections was sufficient or whether publications would be necessary to achieve their goal of coining an acceptable public image for American Jews. Some were concerned that "the preservation of documents alone would not make for a powerful enough public statement" and believed that publications illustrating the contributions of Jews in American history would be necessary. In its early years, however, the AJHS devoted most of its resources to the building of historical collections, especially manuscripts and books (Kaplan E., 2000: 138-140). Later on it moved away from the "warehouse theory" that emphasized data preservation and toward a public role stressing popularization and promotion, as defined in the 1950 modifications to its constitution (Appel J., 1960: 263).

Gathering materials proved difficult, and it took great commitment to archival preservation to succeed in building meaningful collections. Documents were scattered across states and across the Atlantic and beyond; they were often hidden, at best ignored, sometimes damaged and destroyed. Holmio, historian and archivist at the FHSO, wrote about the difficulty of preserving historical material in a non-historically minded community:

More than once it has happened that some farmer has saved materials pertaining to Finnish American life and had notes on various aspects of it, only to have them destroyed as worthless after his death. An incident with ironic overtones occurred once when the archivist went to an old Finnish hall to look for materials of value to the Finnish American Historical Archives. In honor of his coming the hall had been tidied, and in the process invaluable records had been destroyed. (Holmio A., 2001: 392)

This anecdote echoes the experience Learned recounted in 1902 while canvassing the Pennsylvania countryside for archival materials: "Not unfrequently we were greeted with the information, 'If you had only come a little earlier we could have barrels of stuff; only a short time ago we burned a whole mass of books and records as old rubbish."' (Learned M.D., 1911: 6)

Practical considerations played a role in the shaping of collections; but so did the agendas of the ethnic organizations involved. It is well known that early ethnic historical associations were primarily concerned with writing the history of the group in a positive light. Two themes were often emphasized: the pioneers and the lives of great men. The latter allowed the group to demonstrate its contribution to the greatness of the nation, while the former placed the group firmly in the early history of the settlement of the continent. ${ }^{10}$ The importance of these themes is reflected in the 
collections of ethnic historical societies like the AJHS. Kaplan has studied the acquisitions by the society in its early years and found that there was "a special interest in documenting the presence of Jews in North America prior to the Revolutionary War and activities of Jews during the war," with a purpose of demonstrating "a lengthy and firmly rooted American Jewish history, and an American Jewry characterized from the start by patriotic zeal, good work, and a new, American-style piety" (Kaplan E., 2000: 140).

Interest in early settlements corresponds to what David Lowenthal has called "Being First" and what Robert Harney ironically nicknamed "Firstism" or "explorerism" (Harney R., 1982: 19-20; Lowenthal D., 1996: 173) Lowenthal aptly notes that "precedence evokes pride and proves title" (Lowenthal D., 1996: 174). Thus, each group had their founding myth. Major topics in AJHS publications were the participation of Jews to voyages of discovery to America. Finnish- and Swedish-Americans celebrated the anniversaries of the settlement at Fort Christina, and German-Americans the founding of Germantown in Pennsylvania. For Appel, a historian of ethnic historical societies, those institutions' insistence on "firstism" triggered a "chain reaction, whereby the claims of one ethnic group, justified or exaggerated, documented or fanciful, spurred on spokesmen of other groups to assert their 'contributions' to American life" (Appel J., 1960: 320). The need to celebrate pioneers and great men proved to be a lasting one, as it has survived the ethnic revival of the 1960s. This may be because those themes have helped ethnic Americans alleviate the tensions between ethnic distinctiveness and integration, ethnic pride and American patriotism, or, as historian John Bodnar put it, between "cultures of descent and consent" (Bodnar J., 1994: 56).

Of course, archival collections that were started by ethnic historical societies were not limited to documents that illustrated these themes alone. For example, Learned and his colleagues were not just concerned with documenting the lives of the "great men" in German-American history but intended to gather materials on all aspects of the lives of ordinary German-Americans. Learned initiated an ethnographic survey of the GermanAmericans of Lancaster County, in Pennsylvania. The so-called "Conestoga Expedition" consisted in sending field workers among the population to gather archival and artefactual materials representing the agricultural, literary, religious, domestic, social and political aspects of their lives. The survey included diaries, travel narratives, expense reports and many other types of documents ordinarily neglected by archivists as they reflected day-to-day life (Appel J., 1962: 301: Learned M.D., 1903, 1911).

Yet, the complex agendas of the creators of archival collections make us wonder what is missing from those collections. At the AJHS, for example, topics of current interest to Jewish-Americans did not appear until after 1900, such as "Zionism, contemporary antiSemitism, socialism, or recent immigration" (Kaplan E., 2001: 141). Ethnic groups were often divided, but because one of the purposes of preserving the cultural heritage was to strengthen the groups' unity, the resulting collections may well underestimate differences and divisions. The AJHS had a lukewarm attitude toward topics like Zionism and recent immigration because of their controversial nature, which might defeat their chief goal of defining the Jewish-American identity. The deep political divisions between conservatives and socialists or radicals among Finnish-Americans led factions to set up separate cultural heritage institutions or collections, which sometimes competed and clashed over collecting strategies (Daniel D., 2012). Because the FAHA 
was run by conservative Finnish-Americans, socialist groups were reluctant to entrust them with their archival records and were suspicious of the historical narratives preferred by their archivists. Early German-American historiography neglected controversial topics like the history of the German church in American and the influence of German Socialists and Communists (Appel J., 1960: 318).

For the same reason, the scope of the collections was an object of debate as it reflected members' understanding of their own community. By setting up archival institutions and collections, ethnic leaders were aware they would not just mirror the group's existing identity but help shape and project that identity for future generations. They knew that decisions about the scope of the collections would help draw the line between "them" and "us". Thus founders of the AJHS wondered what geographic areas their Society should cover:

Should its scope be limited to the United States, to North America, to the entire New World, to the Western hemisphere? Should it be limited geographically at all? Should it collect from all Jewish denominations, and what about pertinent materials created by non-Jews? Should it allow European members? (Kaplan E., 2000: 139)

As they were well aware, answers to each of these questions would impact the image they intended to create for American Jews. The complexity of their multi-faceted identity defined by their faith, national origin, immigrant or native-born status and language made such decisions contentious. Because of their diversity, Finnish- and German-Americans also struggled with defining the proper scope for their collections (Appel J., 1960: 281-282; Holmio A., 2001: 392).

Growing academic and public interest in immigration and ethnic history, as well as the wider range of available funding in the 1970s and new technologies, helped overcome some of the practical constraints earlier generations had faced. Under the influence of social history, archives started to systematically collect new types of materials documenting ordinary people's lives. As scholarship and politics evolved, the focus shifted from the culture of origin to the experience of transplantation and the difficulties of adjusting to a new world. ${ }^{11}$ Of particular interest to archivists were the ethnic press and the records of immigrant and ethnic organizations like fraternal or temperance societies, which were considered as the vectors of ethnic life and identity (Wynar L.R. and Buttlar L., 1978: xvi).

Computer technologies and the internet have provided new tools and new challenges to ethnic archives. They have allowed scattered collections to find a common space online, as illustrated by the digital collections of the AJHS and four related Jewish institutions. ${ }^{12}$ The ability to assemble and arrange cultural heritage from various geographic origins offers ethnic communities new ways to shape, expand and rekindle ethnic identities, especially for diasporic groups. New Web 2.0 technologies also allow heritage-minded groups to collect materials that went unrecorded earlier. This has been particularly useful to indigenous groups and communities issued from new immigration. Attempts to "decolonize the archive" have made good use of new technologies to empower marginalized voices and democratize access to archives. ${ }^{13}$ Furthermore, alternative forms of documentation, better suited to non-Western cultures, are recognized by information professionals as legitimate sources of identity and memory building - for example, oral histories, tattoos or artistic performances (Bastian J., 2006: 278). 


\section{Conclusion}

Ethnic historical societies and archives are one of the tools ethnic groups use to preserve their heritage. The groups under study have all experienced weakening of the traditional signifiers of ethnicity such as immigrant institutions, foreign language press, or language use - yet they have maintained cultural heritage institutions. Schultz points out that the so-called symbolic ethnicity is not meaningless, and she mentions historical societies but also other institutions or events like festivals and ethnic studies as new signifiers of ethnicity. She encourages fellow historians to raise new questions about such manifestations of ethnicity, which are not "nostalgia for a perceived authentic past" or "a symbolic invention divorced from historical realities" but rather "a historically grounded act of cultural politics" (Schultz A., 2009: 20).

Schultz inspires us to look more closely at ethnic markers like an archives or historical society. She urges historians to consider when and why groups choose them. The basic preservation mission of cultural heritage institutions might lead us to see them as neutral guardians maintaining materials documenting primordial or traditional cultural traits and passing them on to future generations. In fact, such institutions should be seen as instruments or actors in the dynamic process of construction of ethnicity. As mentioned earlier, preservation has as much to do with the present as it has with the past. The construction and celebration of a group's cultural heritage may well be common to all immigrant groups in America, but it is a strategy whose motives and timing are grounded in distinct historical contexts specific to each group. For some, such as the AJHS, cultural heritage institutions were a way to build their image as "safe ethnics". For other groups today, such as indigenous populations, they could be instruments of cultural resistance and independence. For all they can provide convenient, productive and flexible platforms to negotiate the dilemmas of assimilation and resistance.

Furthermore, we know that ethnic groups seek to promote different identities over time. German-Americans rejected their German identity in favour of old stock identification, Finnish-Americans came to terms with their political divisions, and Jewish-Americans contended with their ethnic, religious and political identities. Consequently, the function of cultural heritage institutions may shift over time. Their collections acquire new significance and their management may be negotiated or contested. More studies of such institutions within and between ethnic groups are needed to understand the stakes of ethnic archiving.

\section{BIBLIOGRAPHIE}

Aaltio, Tauri, "A Survey of Emigration from Finland to the United States and Canada”, in Ralph J Jalkanen (eds), The Finns in North America; a Social Symposium, Hancock, Mich., Michigan State University Press, 1969, p. 63-69. 
Anderson, Benedict, Imagined Communities: Reflections on the Origin and Spread of Nationalism, New York, Verso, 2006.

Anderson, James M., “The Evolution and Probable Future of Ethnic Heritage Studies”, Conference of the International Collegiate Academic Council on Ethnic Studies, Cleveland, Ohio, 1979.

Appel, John J., Immigrant Historical Societies in the United States, 1880-1950, New York, Arno Press, 1960.

Appel, John J., "Marion Dexter Learned and the German American Historical Society", The Pennsylvania Magazine of History and Biography, vol. 86, n 3 (July 1962), p. 287-318.

Bastian, Jeannette A., "Reading Colonial Records Through an Archival Lens: The Provenance of Place, Space and Creation", Archival Science 6, no. 3-4 (2006): 267-84.

Black, Brooke M., “Freeing the 'Archival Captive': A Closer Look at Tribal Archives”, Provenance 7 (2005). http://www.provenance.ca/2005-vol7/libraries-archives/native-american-archives-2005black.html. Accessed June 9, 2015.

Blumberg, Barbara, Celebrating the Immigrant: An Administrative History of the Statue of Liberty National Monument, 1952-1982, Cultural Resource Management Study, Division of Cultural Resources North Atlantic Regional Office, National Park Service, 1985. https://archive.org/ details/celebratingimmigooblum. Accessed June 9, 2015.

Bodnar, John E., Remaking America: Public Memory, Commemoration, and Patriotism in the Twentieth Century, Princeton, N.J., Princeton University Press, 1994.

Burton, Antoinette M., Archive Stories: Facts, Fictions, and the Writing of History, Durham, N.C., Duke University Press, 2005.

Cabrera, Rosa M., "Beyond Dust, Memories and Preservation: Roles of Ethnic Museums in Shaping Community Ethnic Identities”, Ph.D. University of Illinois at Chicago, 2008.

Carpenter, Niles, Immigrants and Their Children, New York, Arno Press, 1969 [1927].

Center for Jewish History. http://access.cjh.org/. Accessed June 9, 2015.

Conzen, Kathleen Neils, David A. Gerber, Ewa Morawska, George E. Pozzetta, and Rudolph J. Vecoli, "The Invention of Ethnicity: A Perspective from the U.S.A.", Journal of American Ethnic History, vol. 12, n 1 (Fall 1992), p. 3-41.

Cook, Terry, "The Archive(s) Is a Foreign Country: Historians, Archivists, and the Changing Archival Landscape", The Canadian Historical Review, vol. 90, n 3 (2009), p. 497-534.

Daniel, Dominique, "Documenting the Immigrant and Ethnic Experience in American Archives", The American Archivist, vol. 73, n 1 (Spring 2010), p. 84-102.

Daniel, Dominique, "The Politics of Ethnic Heritage Preservation in Canada: The Case of the Multicultural History Society of Ontario", Information \& Culture vol. 47, n² (Spring 2012), p. 206232.

Daniel, Dominique, “Archival Representations of Immigration and Ethnicity in North American History: From the Ethnicization of Archives to the Archivization of Ethnicity", Archival Science, vol. 14, n² 2 (2014), p. 169-203.

Daniel, Dominique and Amalia S. Levi, (eds), Identity Palimpsests: Archiving Ethnicity in the United States and Canada, Sacramento, Litwin Press, 2014.

Diner, Hasia R., "The Study of American Jewish History: In the Academy, in the Community", Polish American Studies, vol. 65, $\mathrm{n}^{\circ} 1$ (Spring 2008), p. 41-55. 
Harney, Robert, "Ethnic Archival and Library Materials in Canada: Problems of Bibliographic Control and Preservation", Ethnic Forum: Journal of Ethnic Studies and Ethnic Bibliography, $\mathrm{n}^{\circ} 2$ (Fall 1982), p. 3-31.

Hattam, Victoria, In the Shadow of Race: Jews, Latinos, and Immigrant Politics in the United States, Chicago, University of Chicago Press, 2007.

Higham, John, "The Ethnic Historical Society in Changing Times", Journal of American Ethnic History, vol. 13, n² 2 (Winter 1994), p. 30-44.

Holmio, Armas K. E., History of the Finns in Michigan, Detroit, Wayne State University Press, 2001.

Holmio, Armas K. E., and A. William Hoglund. "Foreword”, in Armas K. E., Holmio, History of the Finns in Michigan, Detroit, Wayne State University Press, 2001, p. 7-15.

Japanese American National Museum, "The History of the Japanese American National Museum". http://www.janm.org/about/history/ Accessed June 9, 2015.

Kaplan, Elisabeth, "We Are What We Collect, We Collect What We Are: Archives and the Construction of Identity", The American Archivist, vol. 63, n 1 (April 2000), p. 126-151.

Kazal, Russell A., Becoming Old Stock: The Paradox of German-American Identity, Princeton, N.J., Princeton University Press, 2004.

Koh, Adeline, "Addressing Archival Silence on 19th Century Colonialism - Part 2: Creating a Nineteen Century 'Postcolonial' Archive”, Adeline Koh, March 4, 2012. http:// www.adelinekoh.org/blog/2012/03/04/addressing-archival-silence-on-19th-centurycolonialism-part-2-creating-a-nineteenth-century-postcolonial-archive/. Accessed June 9, 2015. Koh, Adeline, "Decolonizing the Archive”, Digitizing “Chinese Englishmen": Representations of Race and Empire in the Nineteenth Century, n.d.. http://chineseenglishmen.adelinekoh.org/ Accessed June 9, 2015.

Learned, M.D., "The American Ethnographical Survey”, The German American Annals, vol. 1, n 1 (1903), p. 3-7.

Learned, M.D., The American Ethnographical Survey; Conestoga Expedition, 1902, New York, D. Appleton \& Co, 1911.

Lowenthal, David, Possessed by the Past: The Heritage Crusade and the Spoils of History, Free Press, 1996.

Olick, Jeffrey, Vinitzky-Seroussi, Vered and Levi, Daniel, eds., The Collective Memory Reader, London, Oxford University Press, 2012.

Plateau Peoples' Web Portal, “Project Overview”, Plateau Peoples' Web Portal. http:// plateauportal.wsulibs.wsu.edu/html/ppp/help.php?topic=1.Accessed June 9, 2015.

Roediger, David R.,Working Toward Whiteness: How America's Immigrants Became White, New York, Basic Books, 2006.

Schultz, April R., “The Pride of the Race Had Been Touched': The 1925 Norse-American Immigration Centennial and Ethnic Identity", The Journal of American History, vol. 77, n 4 (1991), p. 1265-1295.

Schultz, April R., Ethnicity on Parade: Inventing the Norwegian American Through Celebration, Amherst, University of Massachusetts Press, 2009.

Stoler, Ann Laura, Along the Archival Grain, Princeton University Press, 2010. 
Susag, Chris, "Retaining Modern Nordic-American Identity Amongst Diversity in the United States Today", The Swedish-American Historical Quarterly, vol. 53, n 1 (2002), p. 6-29.

Thernstrom, Stephan, Ann Orlov, and Oscar Handlin, (eds), Harvard Encyclopedia of American Ethnic Groups, annotated edition, Belknap Press of Harvard University Press, 1980.

Trouillot, Michel-Rolph, Silencing the Past: Power and the Production of History, Boston, Mass., Beacon Press, 1995.

Wynar, Lubomyr Roman, and Lois Buttlar, Guide to Ethnic Museums, Libraries, and Archives in the United States, Kent, Ohio, Program for the Study of Ethnic Publications, School of Library Science, Kent State University, 1978.

\section{NOTES}

1. Trouillot distinguishes four moments in the production of history: "the moment of fact creation (the making of sources); the moment of fact assembly (the making of archives); the moment of fact retrieval (the making of narratives); and the moment of retrospective significance (the making of history in the final instance)" (Trouillot M.R., 1995:26).

2. For more on this topic see Daniel D., 2010.

3. For more on memory studies see Olick J., Vinitzky-Seroussi V., and Levi.D., 2012.

4. The paper uses the three ethnic groups as examples to identify key issues about ethnic archiving, but does not purport to present a systematic history of archiving efforts by these groups.

5. The Wynar and Buttlar survey lists organizations by name. The compilation of data and the graph are mine.

6. See for example the debates within the Norwegian Society of America (Schultz A.,1991: 1274)

7. Japanese American National Museum, "The History of the Japanese American National Museum." Accessed June 9, 2015: http://www.janm.org/about/history/

8. See for example Trouillot M.R., 1995; Stoler A.L., 2010; Burton A., 2005.

9. For more on community archives and on relations between them and mainstream institutions, see Daniel D. and Levi A., 2014.

10. For more information on this topic see chapter 3 on the construction of ethnic memory in Bodnar J., 1994.

11. For more information see Daniel D., 2010.

12. Center for Jewish History. http://access.cjh.org/ Accessed June 9, 2015

13. See for example Black B., 2005. http://www.provenance.ca/2005-vol7/libraries-archives/ native-american-archives-2005-black.html Accessed June 9, 2015 ; Plateau Peoples' Web Portal, “Project Overview”, Plateau Peoples' Web Portal, http://plateauportal.wsulibs.wsu.edu/html/ppp/ help.php?topic=1 Accessed June 9, 2015; Koh A., 2012; Koh, n.d.; Daniel D., 2014.

\section{RÉSUMÉS}

Cet article explore les questions auxquelles les groupes ethniques et immigrés ont été confrontés lorsqu'ils ont cherché à constituer leurs archives - à rassembler et préserver les documents qui 
permettent de retracer leur histoire - et à construire leur histoire et leur mémoire collective à travers ces archives. Cet article s'intéresse à trois groupes ethniques - Finlandais, Allemands et Juifs - dans la période qui précède et suit la résurgence ethnique des années 1960. Ces groupes ont été choisis parce qu'ils illustrent l'évolution des archives ethniques chez les communautés immigrées établies avant les années 1920 aux États-Unis. On peut identifier des similitudes et des différences entre ces groupes dans la façon dont ils ont abordé les questions suivantes : qui est responsable de la constitution des archives? Quel doit être le but de ces archives et de la transmission du patrimoine migratoire? Quels documents et quels aspects doivent être préservés et transmis ? De la réponse à ces questions dépendent l'histoire et la mémoire collective de ces groupes et de la nation américaine.

This article will explore some of the issues that immigrant and ethnic groups have dealt with when tackling the task of archiving - gathering and preserving the documents that tell the group's story - and that of history- or memory-building through archives, a process I will refer to, for the sake of convenience, as ethnic archiving. The paper will trace the process of ethnic archiving through the case study of three specific groups-Finnish, German and Jewish communities in the United States-in the period preceding and following the ethnic "revival" of the 1960s. These groups were chosen because they illustrate the evolution of ethnic archiving among immigrant groups that arrived in the United States before the 1920s and the adoption of restrictive immigration laws. The similarities and differences these groups display are visible in the groups' negotiations of, and answers to, the following questions: Who should be responsible for archiving? What should be the purpose of archiving and of the transmission of migration heritage? What should be archived and transmitted? These questions have broad implications for the shaping of history and memory.

Este artículo explora las cuestiones a las cuales se confrontaron los grupos étnicos cuando buscaron constituir sus archivos - reunir y preservar los documentos que permiten trazar su historia - y constituir su historia y su memoria colectiva a través de estos archivos. Este artículo se interesa a tres grupos étnicos - finlandeses, alemanes y judíos - durante el periodo que precede et sigue la resurgencia étnica de la década de los 60 . Estos grupos han sido escogidos porque ilustran la evolución de los archivos étnicos de las comunidades de inmigrantes radicadas en los Estados Unidos antes de los años 1920. Entre estos grupos se puede identificar las similitudes y diferencias de la manera en que ellos abordaron los cuestionamientos siguientes : $i$ quién es responsable de la constitución de los archivos ? ¿ Cuál debe ser el objetivo de estos archivos y de la transmisión del patrimonio migratorio ? ¿Qué documentos y que aspectos deben ser preservados y transmitidos? De la respuesta a estos cuestionamientos dependen la historia y la memoria colectiva de estos grupos y de la nación americana.

\section{INDEX}

Mots-clés : Mémoire, archives, groupes ethniques, identité, Germano-Américains, FinlandaisAméricains, Juifs Américains

Palabras claves : Memoria, archivos, grupos étnicos, identidad, germanoamericanos, finlandeses americanos, judíos americanos

Keywords : Memory, archives, ethnic groups, identity, German Americans, Finnish Americans, Jewish Americans 


\section{AUTEUR}

\section{DOMINIQUE DANIEL}

Dominique Daniel works as a History Librarian and Coordinator of Archives and Special Collections at Oakland University, Michigan. Previously, she was Professor at the University of Tours's English Department. She has published extensively on immigration and ethnicity in both French and English. Her most recent edited book is Identity Palimpsests: Archiving Ethnicity in the U.S. and Canada, co-edited with Amalia Levi. She has also published historical and theoretical articles on cultural heritage institutions documenting the history of immigration and ethnicity. danielatoakland.edu 